Journal of Clinical Investigation

Journal of Clinical In
Vol. 41, No. 4, 1962

\title{
PLASMA LIPOPROTEIN METABOLISM IN PERFUSED RAT LIVERS. I. PROTEIN SYNTHESIS AND ENTRY INTO THE PLASMA*
}

\author{
By DAVID E. HAFT, PAUL S. ROHEIM, ABRAHAM WHITE AND HOWARD A. EDER
}

(From the Departments of Biochemistry, Medicine, and Radiology, Albert Einstein College of Medicine of Yeshiva University, New York, N. Y.)

(Submitted for publication September 21, 1961; accepted November 6, 1961)

It is now clearly recognized that most of the plasma lipids exist as constituents of lipoproteins and that major alterations in plasma lipid concentrations must necessarily occur along with alterations in lipoprotein concentrations. While much attention has been given to the synthesis of lipids and their entry into the plasma, the relationship between the metabolism of the plasma lipids and the metabolism of the proteins to which they are bound is poorly understood.

Studies of the metabolism of the protein portion of the lipoproteins have been made in man and in animals. However, interpretation of these data has been complicated by the existence of multiple pools of precursor and product, and by the existence of multiple sites of production and degradation. To obviate these difficulties, Marsh (1) and Radding and Steinberg (2) have studied lipoprotein synthesis by liver slices, while Radding, Bragdon and Steinberg (3) and Marsh and Whereat (4) employed the method of liver perfusion to measure the synthesis of the protein portion of the lipoproteins. The use of the latter technique eliminates many of the variables present in studies on the whole animal and also certain of the problems associated with the use of liver slices.

Marsh and Whereat (4) have demonstrated net synthesis of low density proteins in the rat liver perfused in situ with red cells suspended in KrebsRinger bicarbonate solution. We have used the isolated rat liver perfused with whole blood. In our initial experiments $(5,6)$ and also in those of Radding and associates (3) it was shown that the rate of incorporation of the amino acid precursor was greater in the low density $(D<1.063)$ frac-

* Supported in part by Training Grants HTS-5265 and HTS-5273 and Research Grants H-2965 and H-2832 from the National Heart Institute, National Institutes of Health, and G-60-55 from the Life Insurance Medical Research Fund, Inc. tion of lipoproteins than in the high density (D 1.063 to 1.21 ) fraction.

In this present study, these observations have been extended, and in some instances synthesis has been studied in two subdivisions of the low density fraction; i.e., the $\mathrm{D}<1.019$ and $\mathrm{D} 1.019$ to 1.063 lipoproteins. We have sought to examine the effect on protein synthesis of factors known to alter the synthesis of a major constituent of the lipoproteins, namely, cholesterol. This problem has also been studied by Radding and Steinberg using liver slices (2).

\section{METHODS}

Animals. Male rats of the Wistar strain weighing 300 to $500 \mathrm{~g}$ were used as blood and liver donors. Rats whose livers were perfused were fed, until time of sacrifice, either on Rockland Farms mouse pellets, or on a diet containing cholesterol, olive oil, and ground pellets in proportion of $1: 10: 50$. The rats used as blood donors were fed the stock ration until 18 hours before they were bled by cardiac puncture; the cholesterol-fed blood donors were given the cholesterol-olive oil diet for 14 days and bled without fasting.

In one series of experiments, rats were exposed to $2,400 \mathrm{r}$ of whole body radiation, 48 hours before their livers were perfused. This dose of radiation was lethal in 3 or 4 days.

Perfusion. The technique of perfusion of the isolated intact .rat liver developed by Miller and associates $(7,8)$ was used. Immediately before perfusion, 100 to $175 \mathrm{ml}$ of blood was obtained from the donor rats by heart puncture with a heparinized syringe. Sixty-five $\mathrm{mg}$ of heparin and $200 \mathrm{mg}$ of glucose were added together with enough Ringer's solution to make the total dilution one-fifth to one-third of the original blood volume. The blood entered the liver through the portal vein and drained from the thoracic portion of the inferior vena cava, while bile was collected through a cannula inserted into the bile duct. The blood supply to the liver was never interrupted for more than 5 minutes. The viability of the liver was judged by the color of the liver, the bile flow, and by occasional liver glycogen measurements. The perfusion pressure was $18 \mathrm{~cm}$ of water and the rate of blood flow was 15 to $25 \mathrm{ml}$ per minute. 
The temperature within the chamber was maintained between $38^{\circ}$ and $40^{\circ} \mathrm{C}$. The blood was continuously oxygenated with a mixture of 95 per cent $\mathrm{O}_{2}$ and 5 per cent $\mathrm{CO}_{2}$. Unless otherwise stated, the length of perfusion was 4 hours.

Uniformly labeled L-lysine-C $\mathrm{C}^{14}$ was used as the isotopic precursor. The total amounts administered varied from 5 to $10 \mathrm{mg}$ and contained between 6.8 and $12.6 \mu \mathrm{c}$; all results were adjusted to a standard dose of $12.6 \mu \mathrm{c}$. Onefourth of the dose was added to the blood in the reservoir at the start of the experiment and the remainder, dissolved in Ringer's solution, was added by slow infusion throughout the perfusion. In two experiments, uniformly labeled L-leucine- $\mathrm{C}^{\mathbf{1 4}}$ was used as a precursor.

Liver cholesterol. Samples of liver weighing 2 to $5 \mathbf{g}$ were homogenized in $15 \mathrm{ml}$ of cold water, and the homogenate was added to $400 \mathrm{ml}$ of $4: 1$ methylal : methanol (Delsal's mixture) (9). After 1 hour the mixture was filtered and the filtrate was dried in a rotary evaporator at a temperature below $45^{\circ} \mathrm{C}$. The extract was dissolved in $30 \mathrm{ml}$ of $2: 1$ chloroform: methanol and washed twice by centrifugation with a $0.003 \mathrm{M} \mathrm{MgCl}$. solution as described by Folch, Lees and Stanley (10). The washed chloroform phase was evaporated to dryness and made up to volume in chloroform. Cholesterol was determined on these extracts by the method of Abell, Levy, Brodie and Kendall (11), and aliquots were taken for determination of specific activity $(12,13)$.

Plasma lipoproteins. The lipoproteins were separated by the method of Havel, Eder and Bragdon (14). The fractions were washed by recentrifugation in salt solutions of appropriate density. This procedure resulted in the removal of some protein and cholesterol from the $\mathrm{D}<1.063$ fraction and a considerable amount of protein but no cholesterol from the D 1.063 to 1.21 fraction. In some of the studies, an additional fraction was obtained first by raising the density of the plasma to 1.019 and centrifuging for 20 hours. The infranatant was then treated as described to obtain D 1.019 to 1.063 and D 1.063 to 1.21 fractions.

Aliquots of each fraction were taken for cholesterol determination. The remainder, after addition of $2 \mathrm{ml}$ of 5 per cent lysine, was dialyzed for 1 day against 0.85 per cent $\mathrm{NaCl}$ and for 1 day against 0.4 to 0.5 per cent $\mathrm{NaCl}$. More carrier lysine was added and the sample was divided into portions for protein precipitation. Initially, proteins were precipitated in 5 per cent trichloroacetic acid and the lipid was extracted from the precipitate with $1: 1$ ethanol: ether. This procedure was abandoned because of difficulty in centrifuging the $\mathrm{D}<1.063$ fraction, which is rich in lipid and low in protein. Subsequently, the following method was adopted. Four equal portions of the sample were pipetted into $225-\mathrm{ml}$ centrifuge bottles and 20 vol of $1: 1$ absolute ethanol: acetone was added to each. After overnight storage at $4^{\circ} \mathrm{C}$, the bottles were centrifuged and the supernatant solution poured off. The protein precipitates were resuspended in 10 to $20 \mathrm{ml}$ of $3: 1$ ethanol: ether, transferred to a $50-\mathrm{ml}$ centrifuge tube, heated at $60^{\circ} \mathrm{C}$ for 3 minutes, centrifuged, and washed once with ether. Two of the four precipitates prepared from a single fraction were dissolved in $5.0 \mathrm{ml}$ of $1 \mathrm{~N}$ $\mathrm{NaOH}$ and, after standing for 2 days at room temperature, analyzed for protein by the method of Lowry, Rosebrough. Farr and Randall (15). Radioactivity was measured on each of the two remaining dried protein precipitates by the following modification of the method of Vaughan, Steinberg and Logan (16): $3.0 \mathrm{ml}$ of $1 \mathrm{~N}$ Hyamine (Rohm \& Haas) in methanol was added and the tube kept in the dark at $60^{\circ} \mathrm{C}$ overnight. One $\mathrm{ml}$ of this solution, together with $14 \mathrm{ml}$ of the phosphor (13) in toluene, was placed in a counting vial, and radioactivity was measured in a Packard liquid scintillation spectrometer. A correction for quenching was obtained by the addition of $5,000 \mathrm{dpm}$ of benzoic acid in $40 \mu 1$ of phosphor solution and recounting.

Albumin was isolated by starch block electrophoresis of the dialyzed $\mathrm{D}>1.21$ proteins. The separation was done in barbital buffer, $\mathrm{pH} 8.6$, at $300 \mathrm{v}$ for 18 hours at $4^{\circ} \mathrm{C}$. Blocks obtained from the front portion of the albumin peak were eluted with 0.85 per cent $\mathrm{NaCl}$ solution and pooled. The protein in samples containing 3 to $15 \mathrm{mg}$ of albumin was precipitated in duplicate by the addition of an equal volume of 20 per cent trichloroacetic acid in the presence of carrier lysine. The precipitates were washed with $1: 1$ acetone: ether, then with ether, and the protein content and radioactivity determined in separate aliquots, as in the case of the lipoproteins.

In several experiments, protein radioactivity was measured after wet combustion with the mixture of Van Slyke, Plazin and Weisiger (17) by assay of the $\mathrm{C}^{14} \mathrm{O}_{2}$ in an ionization chamber with a vibrating reed electrometer. This permitted analysis of the same solution that was used for protein determination. The results did not differ significantly from those obtained by assay of the Hyamine solutions in the liquid scintillation spectrometer.

\section{RESULTS}

Formation of lipoprotein of $D<1.063, D 1.063$ to 1.21, and of albumin. Specific activities of the protein portion of lipoproteins of $\mathrm{D}<1.063, \mathrm{D}$ 1.063 to 1.21 , and of albumin were calculated (Table I). There was appreciable incorporation of the labeled amino acid into both lipoprotein fractions as well as into plasma albumin. The specific activity of the $D<1.063$ fraction was always much greater than that of the D 1.063 to 1.21 fraction, with ratio of activities ranging from 3.3 to 6.8. The specific activity of albumin was between one-fourth and one-half that of the $D$ 1.063 to 1.21 fraction. Despite the variability of the specific activity data among individual experiments, the ratio of specific activities of the two lipoproteins was fairly uniform (Table I). 
TABLE 1

Specific activity (S.A.) of plasma lipoproteins and of albumin in the perfusate

\begin{tabular}{|c|c|c|c|c|c|}
\hline & Expt. no. & $\stackrel{\mathrm{A}}{\mathrm{D} 1.063-1.21}$ & $\begin{array}{c}\mathrm{B} \\
\mathrm{D}<1.063\end{array}$ & Albumin & $\underset{(B / A)}{\text { S.A. ratio }}$ \\
\hline & & $d p m$ & g protein & $\underset{\text { protein }}{d p m / m g}$ & \\
\hline \multirow[t]{2}{*}{$\begin{array}{l}\text { Normal-fed liver donor } \\
\quad \text { (Control) }\end{array}$} & $\begin{array}{l}27 \\
29 \\
33 \\
39 \\
46 \\
51 \\
55^{*}\end{array}$ & $\begin{array}{r}1,300 \\
3,600 \\
2,200 \\
3,400 \\
2,700 \\
2,200 \\
220\end{array}$ & $\begin{array}{r}5,700 \\
12,000 \\
8,600 \\
20,000 \\
11,900 \\
9,100 \\
990\end{array}$ & $\begin{array}{l}845 \\
975 \\
735 \\
680\end{array}$ & $\begin{array}{l}4.4 \\
3.3 \\
3.9 \\
5.9 \\
4.4 \\
4.0 \\
4.5\end{array}$ \\
\hline & Mean $\pm \mathrm{SE}$ & $2,600 \pm 350$ & $11,200 \pm 2,000$ & & $4.3 \pm 0.4$ \\
\hline \multirow[t]{2}{*}{$\begin{array}{l}\text { Cholesterol-fed liver } \\
\text { donor }\end{array}$} & $\begin{array}{l}18 \\
22 \\
25 \\
38 \\
45 \\
47\end{array}$ & $\begin{array}{l}3,400 \\
2,000 \\
1,320 \\
4,000 \\
2,400 \\
2,700\end{array}$ & $\begin{array}{r}23,200 \\
12,000 \\
7,400 \\
16,200 \\
12,000 \\
9,900\end{array}$ & $\begin{array}{r}2,060 \\
\\
630 \\
1,320\end{array}$ & $\begin{array}{l}6.8 \\
6.0 \\
5.6 \\
4.0 \\
5.0 \\
3.7\end{array}$ \\
\hline & Mean $\pm \mathrm{SE}$ & $2,600 \pm 390$ & $13,500 \pm 2,300$ & & $5.2 \pm 0.5$ \\
\hline \multirow[t]{2}{*}{ Irradiated liver donor } & $\begin{array}{l}21 \\
32 \\
37\end{array}$ & $\begin{array}{l}4,200 \\
1,680 \\
3,800\end{array}$ & $\begin{array}{r}16,200 \\
7,100 \\
15,700\end{array}$ & $\begin{array}{r}1,550 \\
840\end{array}$ & $\begin{array}{l}3.9 \\
4.2 \\
4.1\end{array}$ \\
\hline & Mean $\pm \mathrm{SE}$ & $3,200 \pm 480$ & $13,000 \pm 2,600$ & & $4.1 \pm 0.1$ \\
\hline \multirow[t]{2}{*}{$\begin{array}{l}\text { Cholesterol-fed blood } \\
\text { donors }\end{array}$} & $\begin{array}{l}41 \\
42 \\
44 \\
49 \\
54^{*}\end{array}$ & $\begin{array}{r}2,800 \\
2,300 \\
2,100 \\
1,410 \\
250\end{array}$ & $\begin{array}{r}18,000 \\
9,100 \\
13,600 \\
7,200 \\
1,360\end{array}$ & $\begin{array}{l}710 \\
720 \\
560 \\
440\end{array}$ & $\begin{array}{l}6.5 \\
4.0 \\
6.5 \\
5.1 \\
5.4\end{array}$ \\
\hline & Mean $\pm S E$ & $2,200 \pm 290$ & $12,000 \pm 2,400$ & & $5.5 \pm 0.6$ \\
\hline $\begin{array}{l}\text { Chylomicrons added } \\
\text { during perfusion }\end{array}$ & 57 & 1,350 & 5,900 & & 4.4 \\
\hline
\end{tabular}

* In these experiments L-leucine-U-C ${ }^{14}$ was infused for 2 hours, whereas in all others L-lysine-U-C $C^{14}$ was used in perfusions lasting 4 hours. The leucine experiments were not included in the calculation of group averages.

Total activity of the isolated lipoproteins is shown in Table II. Since the absolute amount of protein recovered in the $\mathrm{D} 1.063$ to 1.21 fraction in the control series was about 5 times that in the $\mathrm{D}<1.063$ fraction, the total incorporation into the former was slightly greater in each of these experiments. Interpretation of these data is restricted by the fact that unavoidable losses entailed in the various washings reduced the amount of radioactivity recovered in the isolated lipoproteins, especially in the case of the $\mathrm{D}<1.063$ lipoproteins. Total incorporation into the albumin fraction would be far greater because of its much higher concentration.

In vitro exchange of labeled protein between the two major lipoprotein classes was ruled out by the following study. At the end of a perfusion with $\mathrm{C}^{14}$-leucine the plasma was divided, one portion being incubated for 4 hours at $37^{\circ}$ and the other at $4^{\circ} \mathrm{C}$ for the same period. Each portion was then fractionated in the usual way into $\mathrm{D}<$ 1.063 and $\mathrm{D} 1.063$ to 1.21 lipoproteins. The respective specific activities of the $D<1.063$ and D 1.063 to 1.21 fractions were 990 and $217 \mathrm{dpm}$ per $\mathrm{mg}$ in the refrigerated sample and 965 and $181 \mathrm{dpm}$ per $\mathrm{mg}$ in the sample incubated at $37^{\circ}$ C. Thus, there was no appreciable equilibration of labeled protein due to incubation at $37^{\circ} \mathrm{C}$. Obviously the experiment did not rule out the possible occurrence of an exchange of a fraction of the labeled lipoproteins which was so rapid that it was already complete at the end of perfusion.

The possibility was considered that the different specific activities in the lipoprotein fractions could be due to differing amino acid composition of these fractions, since the composition of rat lipoprotein protein has not been established. Therefore, two experiments were carried out in which 
TABLE II

Total activity of plasma lipoproteins in the perfusate

\begin{tabular}{|c|c|c|c|c|c|}
\hline & \multirow[t]{2}{*}{ Expt. no. } & \multicolumn{2}{|c|}{ D 1.063 to 1.21 protein } & \multicolumn{2}{|c|}{$\mathrm{D}<1.063$ protein } \\
\hline & & $m g$ & $d p m$ & $m g$ & $d p m$ \\
\hline \multirow{7}{*}{$\begin{array}{l}\text { Normal-fed liver donor } \\
\text { (Control) }\end{array}$} & 27 & 26.4 & 35,000 & 5.2 & 30,000 \\
\hline & 29 & 14.3 & 51,000 & 2.1 & 25,000 \\
\hline & $\begin{array}{l}33 \\
39\end{array}$ & 36.5 & 80,000 & 8.0 & 69,000 \\
\hline & $\begin{array}{l}39 \\
46\end{array}$ & $\begin{array}{l}32.0 \\
31.6\end{array}$ & $\begin{array}{r}110,000 \\
85,000\end{array}$ & $\begin{array}{l}3.9 \\
5.2\end{array}$ & $\begin{array}{l}78.000 \\
62.000\end{array}$ \\
\hline & 51 & 27.4 & 61,000 & 5.2 & 47,000 \\
\hline & $55^{*}$ & 22.0 & 4,800 & 4.8 & 4,800 \\
\hline & Mean $\pm \mathrm{SE}$ & $28.0 \pm 3.5$ & $70,000 \pm 11,000$ & $4.9 \pm 0.8$ & $52,000 \pm 6,700$ \\
\hline \multirow{6}{*}{$\begin{array}{l}\text { Cholesterol-fed liver } \\
\text { donor }\end{array}$} & 18 & 15.5 & 52,000 & 4.9 & 114,000 \\
\hline & 22 & 26.4 & 53,000 & 4.7 & 56,000 \\
\hline & 25 & 26.4 & 35,000 & 3.9 & 29,000 \\
\hline & 38 & 20.3 & $\begin{array}{l}81,000 \\
76,000\end{array}$ & $\begin{array}{l}5.7 \\
6.9\end{array}$ & 92,000 \\
\hline & $\begin{array}{l}45 \\
47\end{array}$ & $\begin{array}{l}31.0 \\
28.0\end{array}$ & $\begin{array}{l}76,000 \\
76,000\end{array}$ & $\begin{array}{l}0.9 \\
9.0\end{array}$ & $\begin{array}{l}83,000 \\
89,000\end{array}$ \\
\hline & Mean $\pm \mathrm{SE}$ & $24.7 \pm 2.4$ & $62,000 \pm 7,500$ & $5.8 \pm 0.8$ & $77,000 \pm 14,800$ \\
\hline \multirow[t]{3}{*}{ Irradiated liver donor } & 21 & 20.9 & 88,000 & 5.4 & 87,000 \\
\hline & $\begin{array}{l}32 \\
37\end{array}$ & $\begin{array}{l}29.5 \\
28.2\end{array}$ & $\begin{array}{r}50,000 \\
107,000\end{array}$ & $\begin{array}{l}9.0 \\
6.3\end{array}$ & $\begin{array}{l}64,000 \\
99,000\end{array}$ \\
\hline & Mean $\pm \mathrm{SE}$ & $26.2 \pm 2.7$ & $82,000 \pm 5,200$ & $6.9 \pm 1.1$ & $83,000 \pm 10,300$ \\
\hline \multirow{6}{*}{$\begin{array}{l}\text { Cholesterol-fed blood } \\
\text { donors }\end{array}$} & 41 & 20.1 & 56,000 & 8.0 & 144,000 \\
\hline & 42 & 19.8 & 46,000 & 15.0 & 136,000 \\
\hline & 44 & 28.3 & 60,000 & 9.2 & 125,000 \\
\hline & 49 & 32.0 & 45,000 & 15.3 & 110,000 \\
\hline & $54^{*}$ & 18.7 & 4,750 & 15.0 & 21,000 \\
\hline & Mean $\pm \mathrm{SE}$ & $25.0+3.1$ & $52,000 \pm 3,700$ & $11.9 \pm 1.9$ & $129,000 \pm 5,400$ \\
\hline $\begin{array}{l}\text { Chylomicrons added } \\
\text { during perfusion }\end{array}$ & 57 & 24.6 & 33,000 & 4.5 & 27,000 \\
\hline
\end{tabular}

* See footnote to Table I.

uniformly labeled leucine- $\mathrm{C}^{14}$ was used as precursor (Table I, experiments 54 and 55). Since less radioactivity was used, the specific activities were lower than in the experiments employing lysine as precursor. Nevertheless, the ratio of specific activity in the two lipoprotein fractions was the same as that found in the lysine experiments.

Subfractionation of the $D<1.063$ lipoprotein. In three experiments using livers from rats fed the stock diet, the $\mathrm{D}<1.063$ lipoprotein was divided into two fractions, one of density less than 1.019 and the other of density between 1.019 and 1.063 . It was found (Table III) that the $\mathrm{D}<1.019$ fraction had the highest specific activity of all the lipoprotein fractions, although it accounted for less than half of the total lipoprotein radioactivity recovered because it was present in such low concentration.
The two fractions of higher density, D 1.019 to 1.063 and D 1.063 to 1.21 , had specific activities which were roughly similar to each other. It should be noted that the D 1.019 to 1.063 fraction is combined with the D 1.019 fraction as the "low density lipoprotein" $(\mathrm{D}<1.063)$ in our other experiments (Tables I and II) and in the recent studies of other investigators $(3,4)$.

TABLE III

Specific activity of plasma lipoproteins separated into three classes

\begin{tabular}{lccccc}
\hline Liver donor & $\begin{array}{c}\text { Expt. } \\
\text { no. }\end{array}$ & $\begin{array}{c}\text { Dura- } \\
\text { tion }\end{array}$ & $\begin{array}{c}\text { D } 1.063 \\
\text { to } 1.21\end{array}$ & $\begin{array}{c}\text { D } 1.019 \\
\text { to } 1.063\end{array}$ & D $<1.019$ \\
\hline & & $h r s$ & \multicolumn{3}{c}{$d p m / m g$ protein } \\
Normal-fed & 76 & 1.5 & 1,670 & 940 & 5,060 \\
& 81 & 4 & 1,820 & 1,780 & 6,530 \\
Cholesterol-fed & 84 & 1.5 & 710 & 1,000 & 3,510 \\
& 85 & 1.5 & 980 & 2,310 & 6,500 \\
\hline
\end{tabular}


TABLE IV

Effects of pretreatment of liver donor rat on plasma and liver cholesterol concentrations and on incorporation of acetate1-C $C^{14}$ into liver free cholesterol *

\begin{tabular}{lccc}
\hline & Normal diet & $\begin{array}{c}\text { High-choles- } \\
\text { terol diet }\end{array}$ & Irradiated \\
\hline $\begin{array}{c}\text { Plasma total cho- } \\
\text { lesterol }(\mathrm{mg} /\end{array}$ & $75 \pm 4$ & $101 \dagger \pm 9$ & $116 \pm \pm 16$ \\
$100 \mathrm{ml})$ & {$[8]$} & {$[6]$} & {$[4]$} \\
$\begin{array}{c}\text { Liver total choles- } \\
\text { terol }(\mathrm{mg})\end{array}$ & $\begin{array}{c}186 \pm 8 \\
{[14]}\end{array}$ & $\begin{array}{c}1,430 \ddagger \pm 144 \\
{[16]}\end{array}$ & $\begin{array}{c}196[ \pm \\
{[4]}\end{array}$ \\
$\begin{array}{c}\text { Specific activity of } \\
\text { liver free choles- } \\
\text { terol }(\mathrm{dm} / \mathrm{mg})\end{array}$ & $\begin{array}{c}14,400 \pm 1,700 \\
{[3]}\end{array}$ & $\begin{array}{c}390 \pm \pm 300 \\
{[3]}\end{array}$ & $\begin{array}{c}29,700 \ddagger \pm 1,100 \\
{[3]}\end{array}$ \\
\hline
\end{tabular}

* Data are means $\pm \mathrm{SE}$. Number of observations is given in brackets. † Different from normal average with $\mathrm{p}<0.02$.
\$ Different from normal average with $\mathrm{p}<0.01$.

Effects of alterations in cholesterol biosynthesis. Studies were undertaken to test the influence on protein synthesis and release of factors which are known to produce striking changes in cholesterol biosynthesis. Perfusions with lysine- $\mathrm{C}^{14}$ were carried out using livers of rats which had either been fed cholesterol for 6 days or been exposed to whole body irradiation. As previously observed by other investigators (18-20), the incorporation of acetate- $\mathrm{C}^{14}$ into digitonide-precipitable sterol in the liver was profoundly depressed by cholesterol feeding and was increased by whole body irradiation (Table IV). In both the cholesterol-fed and irradiated animals, plasma cholesterol concentrations were elevated above the normal while liver total cholesterol was increased only in the cholesterol-fed animals.

In contrast to these marked effects on cholesterol synthesis, the specific activities of the two lipoprotein fractions separated were within the range of values found for the normal livers and the ratios of specific activities were within the normal range (Table I). Since the concentrations of protein in the two lipoprotein fractions did not change appreciably, there was no significant change in total incorporation (Table II).

In a single experiment in this series in which the lipoproteins were separated into three fractions, the various specific activities bore the same general relationship to each other as in the experiments with donors fed only chow (Table III, experiment 85).

To test another variable, livers from rats on stock diets were perfused with blood taken from donors which had been on the cholesterol-olive oil regimen for 14 days. The perfusate plasma thus had an elevated cholesterol content at the beginning of perfusion (mean of $84 \mathrm{mg}$ per $100 \mathrm{ml}$ as compared to $41 \mathrm{mg}$ per $100 \mathrm{ml}$ in experiments with normal fasted blood donors). In Table II it is shown that the protein concentrations in the $\mathrm{D}<1.063$ fraction in this series were twice as high as in perfusions using blood donors fed the stock diet. The mean total recovery of protein in the $\mathrm{D}<1.063$ fraction was $4.9 \mathrm{mg}$ in the control experiments and $12.1 \mathrm{mg}$ in experiments using animals whose diets were supplemented with cholesterol. Along with the increase in protein there was unchanged specific activity (Table I), so that the total incorporation of labeled amino acids into this fraction was greatly increased in these perfusions. That increase in protein synthesis in the $\mathrm{D}<1.063$ fraction may be independent of increased plasma lipid levels per se is suggested by the observation that no increase in total incorporation was observed in experiment 57 in which thoracic duct chyle from a rat gavaged with cholesterol and olive oil was added to the perfusate.

\section{DISCUSSION}

It is apparent from these and other studies that the constituents of the plasma lipoproteins, both lipids and protein, are synthesized by the liver.

The fact that the various lipoproteins appear to have differing rates of protein synthesis is undoubtedly an indication of functional heterogeneity. Assuming that the relative amounts of lysine and leucine do not differ markedly between the lipoprotein classes of rat plasma, several conditions remain necessary in order to equate the observed differences in radioactivity of the isolated fractions with corresponding differences in the rate of synthesis: 1) that the presence of radioactivity in the protein precipitate is the result of de novo synthesis of protein, 2) that protein of the various lipoprotein classes is synthesized from a common pool of amino acids or from pools in which the specific activity of the amino acid at the synthetic site is similar, and 3 ) that the proteins isolated are indeed plasma lipoproteins rather than liver proteins not ordinarily found in the plasma.

With regard to the first condition, due precautions were taken against contamination of the 
final precipitates with lysine- $\mathrm{C}^{14}$. When a sham perfusion was performed in which blood containing radioactive lysine was circulated in the absence of a liver, no significant activity was found in the isolated lipoproteins. Furthermore, liver slices have been shown to incorporate labeled amino acids into several peptides which have been isolated by partial hydrolysis from lipoproteins in the medium (2).

Condition 2 could not be examined. If one assumes the existence of a common precursor pool of amino acids, it may be inferred that, in the steady state, the different specific activities in the three lipoprotein fractions mean correspondingly different fractional rates of replacement. Thus, it is concluded that the $\mathrm{D}<1.019$ fraction has a much higher rate of turnover than the D 1.019 to 1.063 and the D 1.063 to 1.21 fractions. Also, the lipoproteins turn over much more rapidly than does plasma albumin. These differing turnover rates have been observed in specific activity-time studies in intact rabbits (21) and in humans (22). It should be noted that in the study of Avigan, Eder and Steinberg (21) in which alanine-1-C $C^{14}$ was administered to intact rabbits, a $\mathrm{D}<1.006$ fraction was isolated and found to have the same specific activity as the D 1.006 to 1.063 fraction. Gitlin and co-workers (22) injected I ${ }^{131}$-labeled lipoproteins into humans, and found the most rapid disappearance of $\mathrm{I}^{131}$ from the $\mathrm{D}<1.000$ lipoproteins $\left(S_{\mathbf{f}} 10\right.$ to 200$)$, while the rate of turnover was slower in the D 1.000 to 1.063 fraction $\left(S_{f} 3\right.$ to 9$)$ and slowest in the $D>1.125$ $(\alpha$-lipoprotein $)$. However, a substantial part of the "turnover" of the first fraction was due to conversion to the second rather than to disappearance from the circulation. In the rat liver perfused in situ, Radding and associates (3) found the $\mathrm{D}<1.063$ fraction to have the highest specific activity; the D 1.063 to 1.21 had about half of this value, and the residual $\mathrm{D}>1.21$ fraction had very much less. When liver slices were incubated in serum with labeled amino acids, the same order of specific activity was found.

The absolute rate of synthesis cannot be calculated from our data because of the lack of measurement of the specific activity of lysine at the synthetic site. Furthermore, it must be considered that each of the isolated lipoprotein fractions is almost certainly a composite of individual lipo- protein proteins each with a different rate of turnover.

We found no evidence of in vitro exchange of labeled protein between the $\mathrm{D}<1.063$ and $\mathrm{D}>$ 1.063 fractions, in agreement with previous observations that these lipoproteins were not interconverted in vivo $(21,22)$. However, we did not test for the possibility of in vitro exchange of protein between the $\mathrm{D}<1.019$ and $\mathrm{D}>1.019$ fractions within the major low density lipoprotein class. If such interconversion had occurred in the perfusate, it would obviously be improper to consider the metabolism of the $\mathrm{D}<1.019$ lipoprotein independently of that of the D 1.019 to 1.063 fraction.

These findings of differing rates of turnover of the various lipoprotein fractions are consistent with data on the metabolism of certain lipid constituents. As is shown in a subsequent study (23), cholesterol esters do not exchange between the different lipoproteins, and they have differing rates of turnover which resemble those of the protein portion when three lipoprotein classes are isolated. When labeled free fatty acids are administered intravenously to intact rabbits and humans, by far the greatest incorporation was found in the $\mathrm{D}<1.006$ fraction (24). This finding, together with our data, suggests that the rapid rate of synthesis of the $\mathrm{D}<1.019$ lipoprotein fraction may be the mechanism whereby lipids can enter the plasma rapidly.

Assumption 3-i.e., that the isolated fractions represent true plasma lipoproteins-is more questionable when it is necessary to isolate lipoproteins from a medium in which liver slices have been incubated. Nevertheless, Radding and Steinberg (2) showed that the D 1.063 to 1.21 lipoproteins secreted into the medium from liver slices were identical with normally circulating high density lipoproteins, according to peptide pattern determination by a modification of Ingram's method. The identity of the $\mathrm{D}<1.063$ lipoproteins could not be established. With the perfused rat liver there is good reason to believe that the lipoproteins isolated are identical with those normally present in plasma. In this preparation, cellular and vascular structures are preserved. The distribution of cholesterol in the lipoproteins of the perfusate is similar to that found in whole rat plasma (14). Also, Marsh and Whereat (4) 
demonstrated that lipoproteins synthesized by a perfused liver are immunochemically similar to lipoproteins of rat plasma.

No coupling between the rate of lipoprotein synthesis and cholesterol synthesis was demonstrated in these studies. These findings are in agreement with those of Radding and Steinberg (2), who used cholesterol feeding and Triton administration to produce variations in cholesterologenesis. Perhaps it could have been anticipated that cholesterol synthesis and lipoprotein production would be unrelated, since the cholesterol which enters the plasma in the newly synthesized lipoproteins may or may not be newly formed. Therefore, the incorporation of acetate into cholesterol need not bear any relationship to the rate of entry of cholesterol into the plasma. Studies undertaken in exploration of this point will be described subsequently (23).

In the experiments in which normal livers were perfused with blood from cholesterol-fed rats, the increase in total concentration of the $\mathrm{D}<1.063$ lipoprotein was so great that losses in isolation were relatively insignificant. Therefore, increased synthesis of this fraction was clearly indicated by measurement of total incorporated radioactivity. One may speculate about possible causes; however, it should be noted that, since the $\mathrm{D}<1.063$ lipoprotein is heterogeneous, the protein whose rate of synthesis was increased may not have been identical with the material which was present in increased concentration.

Although the plasma of cholesterol-fed rats had a markedly elevated low density lipoprotein concentration, we were unable to demonstrate increased synthesis of this fraction in livers taken from such rats. It must be reiterated that comparison of specific activities of the isolated fractions has been emphasized rather than measurement of total incorporated radioactivity, because of unavoidable losses of protein during isolation. When only specific activity is considered, a real increase in synthesis of a particular lipoprotein can be overlooked if it is accompanied by a process tending to introduce unlabeled protein into the lipoprotein fractions; e.g., the addition of lipid to a lipid-poor fraction in amounts sufficient to change its density (25).

It is apparent that in studies of serum lipoproteins care must be taken to separate fractions which have different metabolic activity. The present data show a clear difference in average behavior of three major lipoprotein fractions. It is likely that even more fractions with differing activities will be found when methods for their separation become feasible.

\section{SUM MARY}

The rates of synthesis of high density (D 1.063 to 1.21$)$ and low density $(\mathrm{D}<1.063)$ lipoproteins by the isolated perfused rat liver were compared in experiments in which uniformly labeled L-lysine- $\mathrm{C}^{14}$ was added (by continuous injection) to the perfusing blood. When livers of rats fed a stock diet were perfused with blood from fasted rats, the specific activity of the protein of the $\mathrm{D}<1.063$ fraction was about four times that of the D 1.063 to 1.21 fraction, although the former contained somewhat less than half of the total radioactivity incorporated into lipoprotein protein because of its low concentration in rat plasma. The specific activity of albumin separated by starch block electrophoresis was less than that of either lipoprotein fraction. Neither previous whole-body irradiation nor prefeeding the liver donor with a cholesterol-olive oil regimen caused any significant change in the rates of incorporation of lysine into the major lipoprotein classes, although these treatments markedly influenced cholesterologenesis. When normal livers were perfused with blood from cholesterol-fed rats, there was a twofold increase in the amount of $\mathrm{D}<1.063$ lipoprotein recovered and a corresponding increase in the incorporation of labeled amino acid into this material. When a $\mathrm{D}<1.019$ fraction was separated, it was found that this fraction had a specific activity greatly exceeding that of both the D 1.019 to 1.063 and D 1.063 to 1.21 lipoproteins.

\section{ACKNOWLEDGMENTS}

The authors acknowledge the competent assistance of Mrs. Carol Klein, Mr. Ithamar E. Pollak, and Mr. Gerald Kaplan.

\section{REFERENCES}

1. Marsh, J. B. Net synthesis of low density plasma lipoproteins by rat liver slices. Fed. Proc. 1958, 17, 270. 
2. Radding, C. M., and Steinberg, D. Studies on the synthesis and secretion of serum lipoproteins by rat liver slices. J. clin. Invest. 1960, 39, 1560.

3. Radding, C. M., Bragdon, J. H., and Steinberg, D. The synthesis of low- and high-density lipoproteins by rat liver in vitro. Biochim. biophys. Acta 1958, 30, 443.

4. Marsh, J. B., and Whereat, A. F. The synthesis of plasma lipoprotein by rat liver. J. biol. Chem. 1959, 234, 3196.

5. Haft, D. E., White, A., Roheim, P. S., Walcott, G., Maresca, L., and Eder, H. A. Relationship between synthesis of cholesterol and plasma lipoproteins in the isolated perfused rat liver. Fed. Proc. 1959, 18, 947.

6. Roheim, P. S., Haft, D. E., White, A., and Eder, $\mathrm{H}$. A. Influence of cholesterol concentrations on biosynthesis of proteins in the isolated perfused rat liver. Circulation 1959, 20, 968.

7. Miller, L. L., Bly, C. G., Watson, M. L., and Bale, W. F. The dominant role of the liver in plasma protein synthesis. A direct study of the isolated perfused rat liver with the aid of lysine- $\epsilon-C^{14}$ J. exp. Med. 1951, 94, 431.

8. Green, M., and Miller, L. L. Protein catabolism and protein synthesis in perfused livers of normal and alloxan-diabetic rats. J. biol. Chem. 1960, 235, 3202.

9. Delsal, J. L. Nouveau procédé d'extraction des lipides du sérum par le méthylal. Applications aux microdosages du cholestérol total, des phosphoaminolipides et des protéides. Bull. soc. chim. Biol. 1944, 26, 99.

10. Folch, J., Lees, M., and Stanley, G. H. S. A simple method for the isolation and purification of total lipides from animal tissues. J. biol. Chem. 1957, 226, 497.

11. Abell, L. L., Levy, B. B., Brodie, B. B., and Kendall, F. E. A simplified method for the estimation of total cholesterol in serum and demonstration of its specificity. J. biol. Chem. 1952, 195, 357.

12. Kabara, J. J. A quantitative micromethod for the isolation and liquid scintillation assay of radioactive free and ester cholesterol. J. Lab. clin. Med. 1957, 50, 146.

13. Myant, N. B., and Eder, H. A. The effect of biliary drainage upon the synthesis of cholesterol in the liver. J. Lip. Res. 1961, 2, 363.

14. Havel, R. J., Eder, H. A., and Bragdon. J. H. The distribution and chemical composition of ultracentrifugally separated lipoproteins in human serum. J. clin. Invest. $1955,34,1345$.

15. Lowry, O. H., Rosebrough, N. J., Farr, A. L., and Randall, R. J. Protein measurement with the Folin phenol reagent. J. biol. Chem. 1951, 193, 265.

16. Vaughan, M., Steinberg, D., and Logan, J. Liquid scintillation counting of $\mathrm{C}^{14}$ - and $\mathrm{H}^{3}$-labeled amino acids and proteins. Science 1957, 126, 446.

17. Van Slyke, D. D., Plazin, J., and Weisiger, J. R. Reagents for the Van Slyke-Folch wet carbon combustion. J. biol. Chem. 1951, 191, 299.

18. Tomkins, G. M., Sheppard, H., and Chaikoff, I. L. Cholesterol synthesis by liver. III. Its regulation by ingested cholesterol. J. biol. Chem. 1953, 201, 137.

19. Gould, R. G., Lotz, L. V., and Lilly, E. M. Effect of $\mathrm{X}$-irradiation on hepatic cholesterol synthesis. Fed. Proc. 1956, 15, 264.

20. Bucher, N. L. R., McGarrahan, K., Gould, E., and Loud, A. V. Cholesterol biosynthesis in preparations of liver from normal, fasting, $\mathrm{X}$-irradiated, cholesterol-fed, Triton, or $\Delta^{4}$-cholesten-3-one-treated rats. J. biol. Chem. 1959, 234, 262.

21. Avigan, J., Eder, H. A., and Steinberg, D. Metabolism of the protein moiety of rabbit serum lipoproteins. Proc. Soc. exp. Biol. (N. Y.) 1957, 95, 429.

22. Gitlin, D., Cornwell, D. G., Nakasato, D.. Oncley, J. L., Hughes, IV. L., Jr., and Janeway, C. A. Studies on the metabolism of plasma proteins in the nephrotic syndrome. II. The lipoproteins. J. clin. Invest. 1958, 37, 172.

23. Roheim, P. S., Haft, D. E., White, A., and Eder, H. A. Unpublished results.

24. Havel, R. J. Conversion of plasma free fatty acids into triglycerides of plasma lipoprotein fractions in man. Metabolism 1961, 10, 1031.

25. Scanu, A., and Hughes, W. L. Recombining capacity toward lipids of the protein moiety of human serum $\alpha_{1}$-lipoprotein. J. biol. Chem. 1960, 235, 2876. 